\title{
CONVEYING THE SELF IN A FOREIGN LANGUAGE: EXPLORING JFL LEARNERS' SELF-INTRODUCTION
}

\author{
Kiyomi FUJII \\ Kanazawa Institute of Technology, Japan \\ kfujii@neptune.kanazawa-it.ac.jp
}

\author{
Naomi YANAGIDA \\ Hitotsubashi University, Japan \\ n.yanagida@r.hit-u.ac.jp
}

\begin{abstract}
In this study, the authors researched how learners of Japanese as a foreign language introduce themselves and what they want to convey, as well as what kind of skills the speakers need to effectively communicate these points to the addressee. The self-introduction video data were collected from a project in which JFL learners interacted with EFL learners through Facebook. The survey data included learners' evaluations of their own self-introductions. Interviews were conducted with students in counterpart schools to evaluate the learners' self-introductions. The authors analyzed the data and extrapolated the most useful skills for effective conveyance from the most successful self-introductions. The results showed discrepancies between learners' self-evaluations and the opinions of the addressees. Non-verbal communication strategies were also shown to play an important role in successful conveyances. In this paper, we provide a brief overview of the project and report salient results obtained through the analysis of the data. We also share pedagogical implications of the results, and suggest alternative approaches to language pedagogy.
\end{abstract}

Keywords: learners of Japanese as a foreign language; self-introduction; self-evaluation

\section{Povzetek}

V raziskavi avtorici raziščeta, na kakšen način se učenci japonskega jezika predstavijo in kaj želijo pri tem povedati. Obenem analizirata, katere spretnosti učenci potrebujejo, da lahko uspešno podajo željene informacije. $\mathrm{V}$ raziskavi so bili uporabljeni videoposnetki samopredstavitev iz projekta, v katerem so učenci japonskega jezika komunicirali z učenci angleškega jezika preko platforme Facebook. Zbrani podatki vključujejo samoevalvacije učencev in intervjuje z njihovimi sogovorniki, v katerih so tudi sogovorniki podali oceno samopredstavitev. Avtorici sta analizirali podatke in iz najboljših samopredstavitev predvideli najbolj uporabne spretnosti podajanja 
informacij. Rezultati so pokazali precejšnjo razliko med samoevalvacijami in ocenami, ki so jih o samopredstavitvah podali sogovorniki. Iz podatkov je bilo tudi razvidno, da neverbalna komunikacija igra pomembno vlogo pri uspešnosti podajanja informacij. Članek predstavi splošen pregled projekta in najpomembnejše rezultate analize, ki jih avtorici na koncu pedagoško ovrednotita ter na osnovi le-teh predlagata alternativne pristope $\mathrm{k}$ poučevanju tujega jezika.

Ključne besede: učenci japonščine kot tujega jezika; samopredstavitev; samoevalvacija

\section{Introduction}

Language education needs to respond to individual needs, but so far, many language lessons focus on providing learners particular sets of patterns. For example, there are sets of self-introduction patterns for which learners essentially fill in the blanks to "create" their own self-introductions. However, this activity rarely transcends a template word game and is far from a creative endeavor. Learners who want to express their own personalities are often limited by those set patterns and cannot effectively convey their own individuality. As a result, almost everyone begins to sound like the same person.

In the present study, the researchers interrogate the current language-learning environment and argue for a syllabus that reflects individual needs, in contrast to the more common functional syllabus, or even the situational (bamen) syllabus (Kobayashi, 2005, 2016; Sato et. al., 2015). We focus on JFL learners' self-introductions and what they try to convey, as well as how learners introduce themselves and what kind of skills the speakers need to effectively communicate these points to the addressee.

\section{Literature Review}

To date, much research has been conducted on how language learners' linguistic performance is judged. The research indicates that learners' linguistic performance evaluations largely depend on the evaluator. This applies to the evaluation of JFL learners' writing (Usami, Mori, \& Yoshida 2009), speech performance (Ishihara, Tsurutani, \& Tsukada 2011; Saito \& Akiyama 2017; Tsurutani, 2010), and conversation (Choi 2008, 2013; Morimoto, Mizukami, \& Yanagida 2013; Nohara 2009, 2011; Watanabe 2005a, 2005b).

For example, Tsurutani's 2010 study indicates that native Japanese college students who did not have any contact with non-Japanese judged L2 Japanese learners pronunciation based on accuracy of timing rather than pitch accent (Tsurutani 2010). A further study examined four groups of evaluators: Japanese language teachers, nonlanguage teachers, beginner-level JFL learners, and advanced level JFL learners to see how they evaluate JFL learner speech (pitch and timing in sentences). The results 
showed that, somewhat predictably, Japanese language teachers give more strict judgments than non-teachers, and advanced learners are stricter than beginner-level learners (Ishihara, Tsurutani, \& Tsukada 2011).

Watanabe (2005a) studied how native speakers who are also Japanese language teachers $(n=25)$ or college students $(n=25)$ evaluate JFL learner conversations with Japanese college students to discern criteria for positive and negative evaluation. The results showed that Japanese teachers tend to evaluate negatively for sociolinguistic competence (such as failure to use honorifics), but Japanese college students, in contrast, give positive evaluations for the same lack of honorifics. Watanabe (2005a) also showed that both teachers and students evaluate grammar and pronunciation errors negatively. On the other hand, vocabulary and expressions such as wakamonokotoba (youth slang) and discourse and communication competence, such as non-verbal communication (using gestures and fillers), were positively evaluated. Nohara's (2011) study also found that Japanese language teachers focus on linguistic performance, but non-teachers tend to focus more on the speakers' attitude. Other studies (e.g., Choi 2008, 2013) also examined Japanese teacher and non-teacher evaluations of JFL conversations and found similar results, namely that non-verbal communication strategies, such as paralinguistic competence, are evaluated positively by both groups.

Iwasaki (2013) investigated JFL learners' ( $n=5$ ) use of hedges such as nanka or chotto, and looked at how Japanese young people, namely college students ( $\mathrm{n} 60$ ), feel about their sociability. JFL learners' discourses were recorded before and after study abroad, and the frequency of hedges and raters' evaluations were compared. The results demonstrated that, after a study abroad, the JFL learners' use of hedges increased significantly, as did the ratings by college students. Iwasaki claimed JFL learners who use hedges frequently are able 'to socially package their messages effectively' (Iwasaki, 2013, p. 263) as well as to 'project their identity as young adults' (Iwasaki, 2013, p. 263). Although Iwasaki mainly concentrated on JFL learners rather than raters, her data provides insights into the judgments of a specific rater demographic.

The studies mentioned above indicate that the evaluations of learners' linguistic performance are contingent upon the evaluator. However, there are few studies that focus on the learners' intentions. A notable exception is Siegal's (1994, 1995, 1996) study of four adult women learning Japanese in Japan. This ethnographic research focused on language use associated with the image JFL learners wanted to present. The JFL learners were aware of the different speech styles associated with expressing politeness. As one of her participants, Mary often thought she could not express certain 'subtleties' like she could in English. In cases of learners wanting to express deference or politeness, this gap seems larger for adult learners. However, interlocutors did not necessarily view pragmatic inappropriateness as a failure (Siegal, 1995, 1996). With 
regard to these issues, many scholars note the recent moves in language education away from teaching methodologies that strictly focus on standardized content (Kobayashi, 2005, 2016; Sato et. al., 2015). Noda (2005), for instance, argues that it is time to revisit language education and shift focus from grammar and teaching sets of grammatical structures to developing skills suited to individual needs. To wit, rather than teaching standardized grammatical points, content should be adjusted to better fit individual needs (Noda, 2005, p. 18). Kobayashi (2005) also supports this position, contending that so-called beginner Japanese grammar does not include the learner's point of view.

To further mine this area, we focused on JFL learner intention in the present study by examining their self-introductions along with what they were attempting to convey. We also analyzed how learners introduced themselves and what kind of skills the speakers needed to effectively communicate these points to the addressee.

\section{Method}

\subsection{Project Overview}

The project comprised exchanges between JFL and EFL learners at universities in the U.S. and Japan, lasting from September 2016 to December 2016. The purpose was to encourage students to go beyond classroom learning into voluntary, self-directed learning outside the classroom, as well as using the target language in practical and personal ways. The project contained a series of tasks involving video and written exchanges via private Japanese and English Facebook group pages created by the instructors. On the Japanese page, JFL learners posted their videos in Japanese, and native Japanese college students (EFL learners) posted their comments in Japanese. Conversely, on the English page, EFL learners posted their videos in English and American college students commented in English. In these assignments, students introduced themselves, talked about their campus, and explained their favorite activities.

The participants in this study were $66 \mathrm{JFL}$ and $51 \mathrm{EFL}$ learners from the exchange project. The JFL learners were enrolled into third- and fifth-semester Japanese courses in the US., and their Japanese proficiency level was novice-high to intermediate-high. The EFL learners were enrolled in a Basic English course at a science and engineering university in Japan. 


\subsection{Materials}

\subsubsection{Questionnaire}

We conducted surveys of JFL learner participants, with questions tailored specifically to their video self-introductions (Appendix A). The questions were the following: 1) How would you describe "yourself"? Write the key words that capture how you see yourself, 2) Do you think you were able to show "yourself" as you intended to in a Facebook video? If yes, what kind of things did you try, or how did you show who you are in the video? If no, why do you think you could not show who you are? What was difficult about it? The questionnaire was administered in English and all questionnaire data were collected and used to create a self-description sheet.

\subsubsection{Self-introduction videos}

Self-introduction videos were likewise collected from the Facebook-based project described above. There were three JFL classes and three EFL classes, allowing for a oneto-one class pairing. All students created the videos to introduce themselves to their counterparts at the beginning of the project. However, the due date for the EFL side was scheduled earlier than the JFL learners' date, which gave the JFL learners the chance to see their counterparts' videos and gave them some idea as to their audience for their self-introductions.

\subsection{Data collection procedure}

After the questionnaire data were collected, we selected JFL learners who provided detailed answers to Question 1). Among those selected JFL learners, six answered "yes" and seven answered "no" to Question 2). We created a list of self-descriptions for the 13 learners based on Question 1). We collected these 13 learners' self-introduction videos from the dedicated Facebook page and created a single 11.5-minute video of six patterns from the introductions. To avoid showing the same order of patterns, we further created differing patterns for the order of self introductions. Additionally, we gathered questionnaire data from those $13 \mathrm{JFL}$ learner self-descriptions in English. Referenced by Morimoto, Mizukami, \& Yanagida (2013), all description words were listed and translated into Japanese. During this process, redundant description words were eliminated and similar words were merged into one translation. For example, the words "talkative" and "verbose" were merged into the Japanese word oshaberina. The list consisted of 36 Japanese words and served as a document for the Japanese students' to use when they reviewed the JFL learners' self-introduction videos.

The video clips were shown to six Japanese students (three male and three female) who participated in the project (Table 1). None of them had any non-Japanese friends 
or acquaintances at that point. They were asked to mark the list on the self-description sheet based on their impressions of JFL learners. Semi-structured follow-up interviews were conducted with Japanese students, in Japanese, to discern the reasoning for their evaluations. The authors translated the interview data into English.

Table 1: Japanese students' rater profiles

\begin{tabular}{lccl}
\hline Rater & Age & Sex & Major (Minor) \\
\hline A & 20 & F & Psychological informatics \\
B & 20 & F & Psychological informatics \\
C & 20 & M & Civil and environmental engineering \\
D & 19 & F & Media information \\
E & 20 & M & Media information \\
F & 19 & M & Mechanical engineering \\
\hline
\end{tabular}

\subsection{Data collection procedure}

This study focused on JFL learners (three males and three females) who claimed they could express themselves in their videos. Table 2 lists these 6 (out of 13) learners' profiles and self-introduction video information.

We compared these learners' self-descriptions with Japanese-native students' judgments, expressed in the vocabulary list that Japanese students marked while watching JFL learners' videos. We created 14 identical sheets for each Japanese student, one for testing and 13 for JFL learner videos. The authors first independently divided the data into five categories based on NEO Personality Inventory-Revised (NEO PI-R) (Costa et al 2011; Shimonaka et al. 1998) and then consulted with each other to determine the final categorization. This inventory was originally developed to assess individual personalities (Costa, McCrae, \& Kay 1995). We used this inventory primarily because of its widespread use. The NEO PI-R has 60 items to provide five basic personality factors: neuroticism, extraversion, openness to experience, agreeableness, and conscientiousness. For example, the self-description "outgoing" is categorized as a positive item under extraversion, while "reserved" is categorized as a negative item under extraversion. Categorized data were first rated giving one positive item 10 points, and one negative item negative 10 points, the aggregate of which gave us the point totals. Furthermore, we standardized both groups' points to compare JFL learners' selfdescriptions and Japanese students' evaluations.

A native Japanese research assistant transcribed the interview data for analysis. Based on the interview data, we divided Japanese students' evaluations according to how they made their decisions while watching the JFL leaners' videos. Following Argyle (1994) and Poyatos (1992), we divided the judgments into verbal and non-verbal communication factors. Using the JFL learner data from the questionnaire 
demonstrated what kinds of skills, such as verbal expressions or non-verbal cues, they used to best represent themselves in the videos.

Table 2: JFL learner profiles and self-introduction video information

\begin{tabular}{|c|c|c|c|c|}
\hline Student \# & Sex & Major (Minor) & Length of video & \# of sentences \\
\hline 1 & $\mathrm{M}$ & Math and Art & $1: 08$ & 6 \\
\hline 2 & $\mathrm{~F}$ & Linguistics & $0: 55$ & 10 \\
\hline 3 & $M$ & Anthropology (Japanese language) & 1:06 & 10 \\
\hline 4 & $\mathrm{M}$ & Science engineering (Japanese literature) & $0: 27$ & 6 \\
\hline 5 & $\mathrm{~F}$ & Computer engineering & $1: 25$ & 19 \\
\hline 6 & $\mathrm{~F}$ & Business & $0: 35$ & 10 \\
\hline
\end{tabular}

\section{Results and discussion}

\subsection{JFL learner and rater judgments}

Figure 1 shows the results of JFL learners' self-descriptions against the judgment of the raters. S stands for "student," and the numbers correspond to the student number in Table 2. The solid lines indicate the JFL learners' self-description and the dotted lines indicate the rating of the Japanese evaluators. Although most JFL learners' selfdescriptions differed from the rater's evaluation results, one learner's (S3) selfdescription was very close.

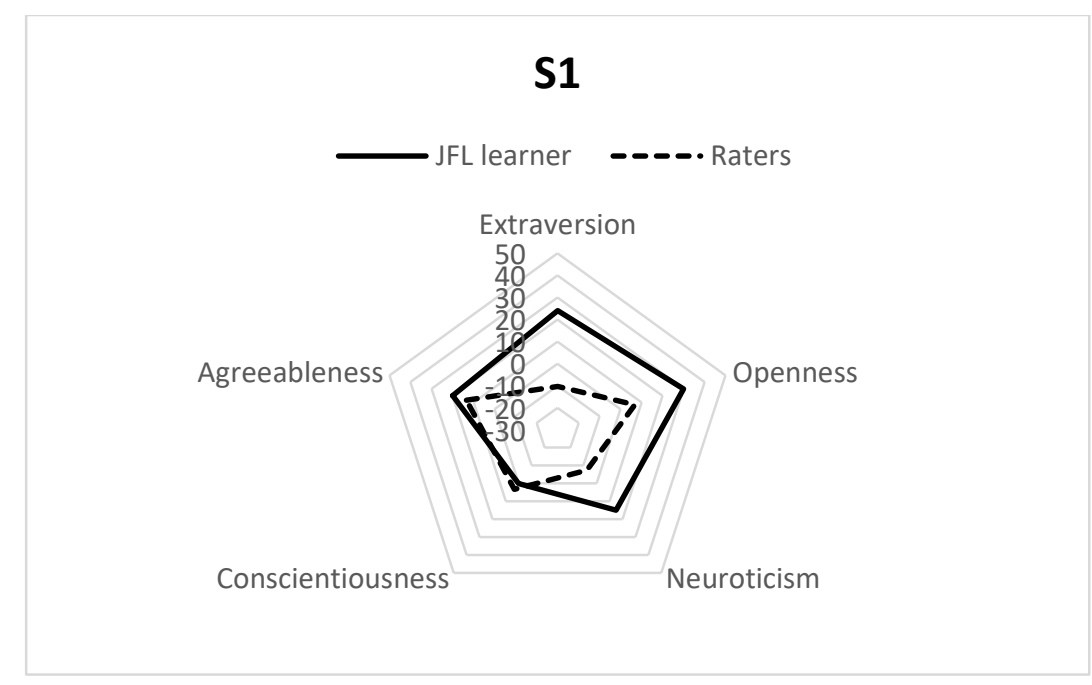




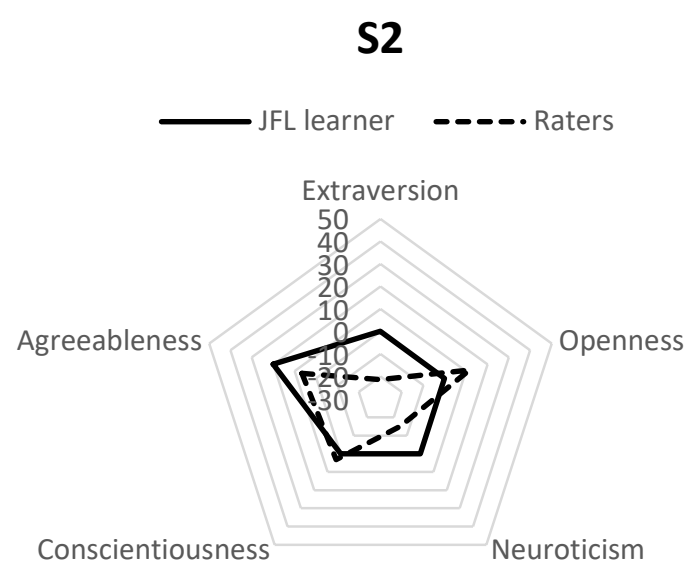

S3

- JFL learner _----・Raters

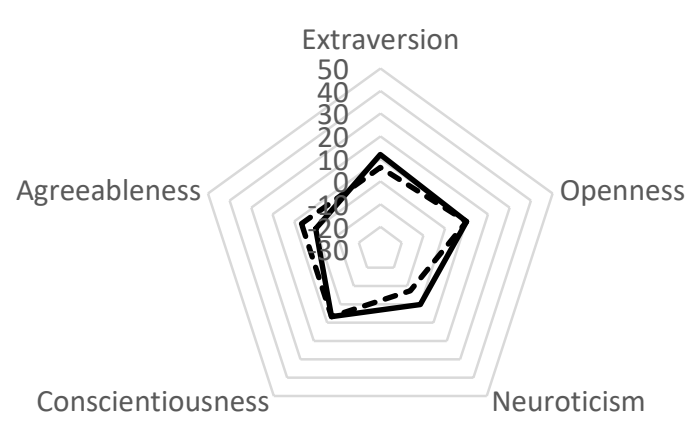

S4

- JFL learner _----・Raters

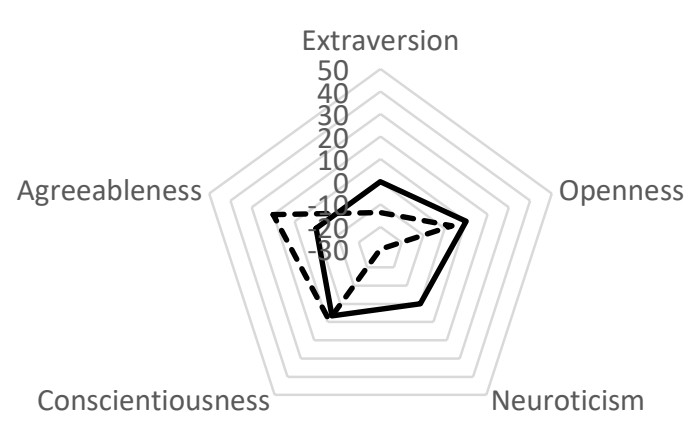




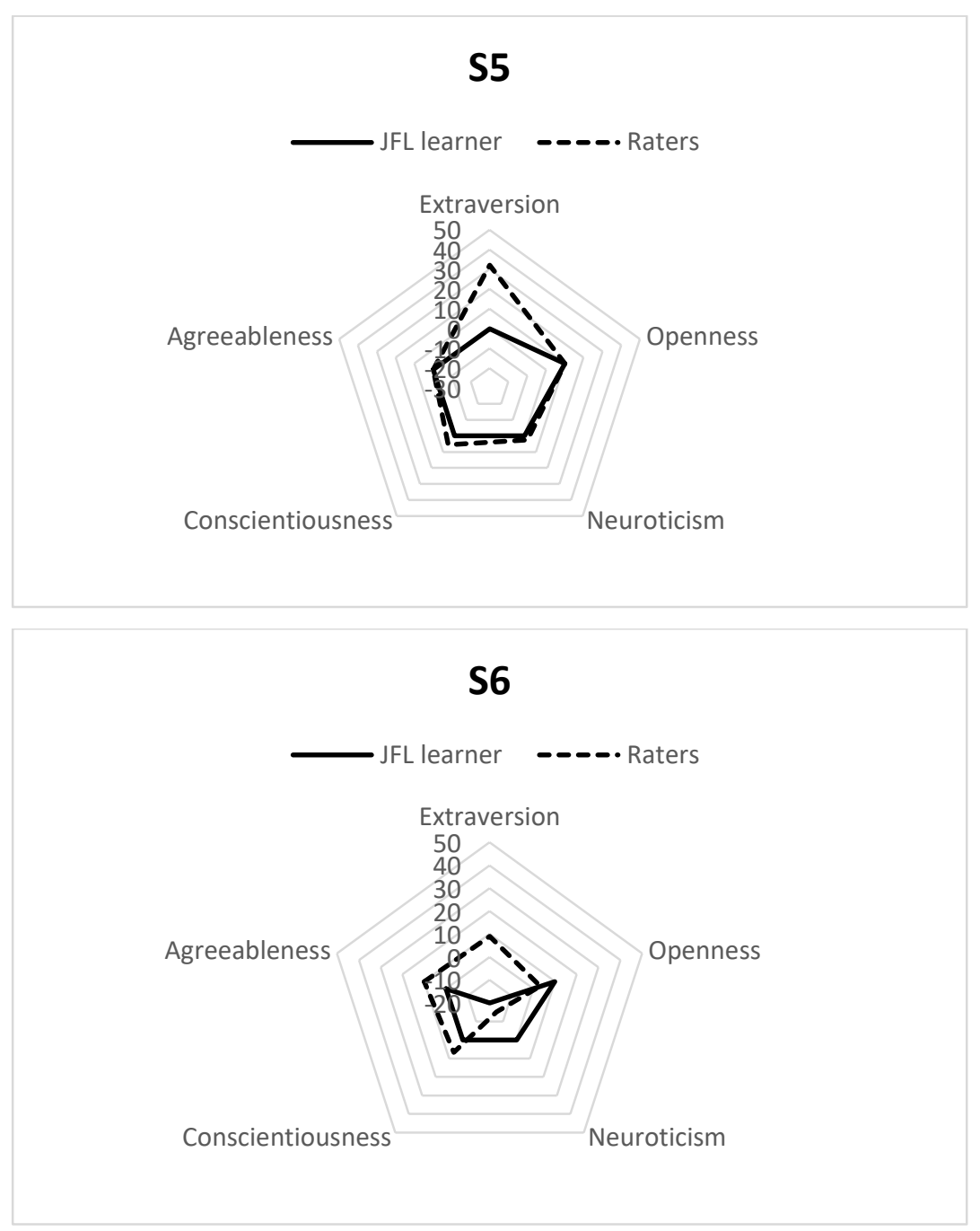

Figure 1: JFL learners' self descriptions and raters' judgments

\subsection{JFL learners' intentions and evaluation factors}

Based on the Japanese students' rating data, which we collected during a follow-up interview, we examined the factors behind their judgments. Figure 2 illustrates the results. Each JFL learner's self-description was examined based on whether the raters' decisions were made on verbal or non-verbal communication factors. For example, if the raters' evaluations were based on a story content, we categorized it as a verbal factor, but when the evaluations were based on paralinguistic aspects such as gestures or learner's appearance, we categorized these as non-verbal factors. As shown in Figure 2 , most judgments were motivated by non-verbal factors.

The majority of comments we received from the raters had to do with paralinguistic factors, tone and volume of voice, and speed of speech, covered under 'the way they talk' (39\%). At the interview we confirmed the specific rating for 'the way 
they talk.' In this instance 'speaking slowly' resulted in the rating of 'calm,' whereas 'speaking energetically' led to the rating of an 'energetic person.' The raters also rated JFL learners' facial expressions (9\%) and gestures (7\%). For example, smiling was taken to be a sign of a 'friendly person,' and bowing at the beginning or end of the selfintroduction resulted in a rating of 'respectful person.' The rater's decisions were made by mostly non-verbal factors as the previous researchers indicated.

In the next section, we focus on two cases in which learner's self-description and raters' judgments differed the most (S1) and the least (S3).

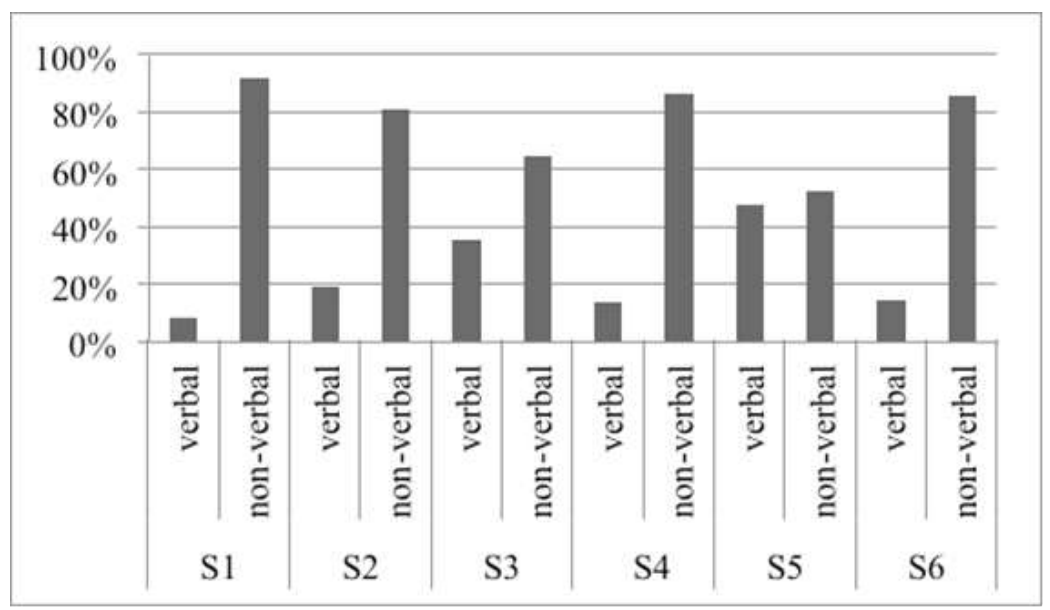

Figure 2: Factors for raters' judgments

\subsection{Qualitative analysis}

As we previously described, the interview data discussed in this section was translated from Japanese to English by the authors. We can see from Figures 1 and 2, in instances where evaluations were motivated by non-verbal factors, the learners' selfdescriptions and raters' judgments differed greatly. For example, S1 self-described as 'loud, happy, busy, high-strung, independent, creative, energetic, smart, verbose, caring,' mentioning, 'I was able to give my answers my own personal spin. I used gesticulations similar to how I do in English. I felt fairly confident as a communicator.' (S1) However, when the raters were questioned about their evaluations, they responded: 'I thought S1 was very shy because S1 looked away (rater C).' or else 'S1 spoke slowly and did not move much, so I thought S1 was a very quiet person (rater D).' Other raters said, 'When S1 made a big gesture, I thought this was a funny person (omoshiroi hito) (rater E).' and 'Since talking about doing comedy, I thought S1 was a creative person (raters B \& F). '. S1's method of 'using gesticulations' did not work as much as she or he expected. 
On the other hand, when the raters' judgments were informed by verbal factors, the learner's self-description and the raters' judgments were much more in line, such as S3 and S5. S3's self-description was 'nice, respectful, curious, fun-loving,' as S3 explained, 'I tried to show that I was interested in differences in personal experience between myself and Japanese students. I tried to do this by asking questions about their experiences (S3).' The raters commented on non-verbal factors. Rater B for example said that 'As soon as S3 started to speak S3 was really energetic, and from the way she or he spoke, S3 was very friendly'. Some raters were also motivated by S3's verbal factors: 'S3 talked about learning dialects and I thought S3 was a very fun and friendly person (rater $\mathrm{C}$ )' and 'S3 is a very curious person since s/he is studying kansai ben (kansai dialect) (rater F).' One rater added that 'S3 called out to us saying to work hard, which made me think S3 was a hard working person (rater F).'

It is clear from the raters' comments about S1 and S3 that both non-verbal and verbal factors strongly affect their judgments. This indicates that for an effective selfintroduction (here defined as matching closely with the native-speaker evaluations), it is crucial for JFL learners to develop skills that enable them to verbally express their personality rather than simply memorizing set grammatical patterns, which seems to be the standard approach. These results also suggest that JFL learners' intuitions about effective use (here defined as matching closely with the native-speaker evaluations) of non-verbal communication are generally unreliable. This seems to hold true at least at this level of Japanese ability. It would be instructive to conduct a similar study with higher-level JFL learners to see if their use of non-verbal strategies proves more successful, especially since higher-level students are also likely to have more cultural not strictly linguistic - exposure. Nevertheless, there is a way to train such intuitions in a systematic manner. We believe that the syllabus that corresponds with individual needs (Kobayashi, 2005, 2016; Sato et. al., 2015) provides the tools that learners need to express themselves.

\section{Conclusion}

In this study, we investigated JFL learners' self-introductions, along with what they were attempting to convey, to shed light on how learners introduce themselves, and what kind of skills the speakers need to effectively communicate these points to the addressee. The results support findings of previous studies, showing that non-verbal factors play an important role in L2 learners' utterances. However, our results also indicated that the learners' self-description and raters' judgments were closest when judgments were based on verbal aspects. For language learners, self-introductions often constitute the first steps and may seem easy for non-novice learners, but it might be worth devoting more attention and practice to what it is one truly wants to convey. We believe a syllabus that focuses more on the individual (Kobayashi, 2005, 2016; Sato 
et al., 2015) provides one of the most effective ways for language learners to achieve this goal. Although the current study suggests that learners need both non-verbal and verbal skills to effectively communicate, the data set was rather small, and we need to continue collecting data and conducting research in this area.

\section{Acknowledgement}

This study was supported by JSPS KAKENHI, Grants-in-Aid for Challenging Research No. 15K12899 and National Institute for Japanese Language and Linguistics, Collaborative Research Projects.

\section{References}

Argyle, M. (1994). The psychology of interpersonal behavior. Penguin UK. ISBN 0140273742

Choi, M. 崔文姫 (2008). Kankokujin nihongogakushûsha no hatsuwa nitaisuru nihongobogowasha no inshôkeisei: kotonaru zokusei wo motsu bogowasha no hyûka no sûi 韓国人日本語学習者の発話に対する日本語母語話者の印象形成: 異なる属性を 持つ母語話者の評価の相違 [Japanese native speakers' assessment of Japanese learners' discourse: how Koreans learning Japanese impress Japanese people and what factors are involved]. Nihongokenkyû 日本語研究, 28, 1-15. ISSN 03866084

Choi, M. 崔文姫 (2013). Nihongogakushûsha no hatsuwa nitaisuru nihongobogowasha no hyôka: Nihongokyôshi to hinihongokyôshi no ingamoderu wo shushinni 日本語学習者の 発話に対する日本語母語話者の評価:日本語教師と非日本語教師の因果竹”ルを心 $に$ [Japanese native speakers' evaluation of Japanese learners' utterances : Cause-andeffect models for Japanese teachers and non-teachers], Kokuritsu kokugo kenkyûjo ronshû 国立国語研究所論集 National Institute for Japanese Language and Linguistics Research Papers, 5, 1-16. ISSN 2186-134X. DOI 10.15084/00000501

Costa, P. T. Jr., McCrae, R. R., \& Kay, G. G. (1995). Persons, places, and personality: Career assessment using the revised NEO personality inventory. Journal of Career Assessment, 3 (2), 123-139. DOI 10.1177/106907279500300202

Costa, P. T. Jr., McCrae, R. R., Shimonaka, Y., Nakazato, K., Gondo, Y., \& Takayama, M. Paul T. Costa・ Robert R McCrea・下仲順子・中里克治・権藤恭之・高山緑(2011). Nihonban NEO$P I-R, N E O-F F I$ shiyômanyuaru 日本版 NEO-PI-R, NEO-FFI 試用マニュアル [NEO-PI-R, NEO-FFI manual for the Japanese version Big5 personality inventory] Tokyo Japan: Tokyoshinri 東 京心理. ISBN 4924552011

Ishihara, S., Tsurutani, C., \& Tsukada, K. (2011). What constitutes 'good pronunciation'from L2 Japanese learners' and native speakers' perspectives? A perception study. Electronic Journal of Foreign Language Teaching, 8 (Suppl. 1), 277-290. ISSN 0219-9874

Iwasaki, N. (2013). Getting over the hedge: Acquisition of mitigating language in L2 Japanese. In C. Kinginger, (Ed.), Social and Cultural Aspects of Language Learning in Study Abroad. Language Learning \& Language Teaching 37, (pp. 239-267). Philadelphia Amsterdam: John Benjamins Publishing Company. ISBN 9789027213167 
Kobayashi, M. 小林汁 (2005). Komyunikeeshon ni yakudatsu nihongokyôikubunpô コミュニケーション に役立つ日本語教育文法. In H. Noda (Ed.) 野田尚史(編), Komyunikeeshon notameno nihongokyôikubunpô コミュニケーションのための日本語教育文法, (pp. 23-42). Tokyo, Japan: Kuroshio Publishers くろしお出版. ISBN 4874243347

Kobayashi, M. 小林汁 (2016). Fukugengo, fukubunkajidai no nihongokyôiku niokeru nihongokyôshiyôsei 複言語・複文化時代の日本語教育における日本語教師飬成. In H. Honda \& M. Matsuda 本田弘之・松田真紀子(Eds.), Fukugengo, fukubunkajidai no nihongokyôiku: watashitachinokotobatoha? 複言語・複文化時代の日本語教育:わたし たちのことばとは?[Japanese language education in the era of plurilingualism and pluriculturalism] (pp.135-162). Tokyo, Japan: Bonjinsha 凡人社. ISBN 9784893589125

Morimoto, I., Mizukami, E., \& Yanagida, Y. 森本郁代·水上悦雄・柳田直美(2013). Ryûgakusei ni yoru hanashiai ni tai suru hyôka ni eikyô o ataeru komyunikeeshon kôdô 留学生によ る話し合いに対する評価に影響を与えるコミュニケーション行動 [The effect of communication behaviors on the evaluation of group discussions by Japanese language learners]. Sôgô seisaku kenkyû 総合政策研究[Journal of Policy Studies], 44, 41-52. ISSN 1341996X [http://hdl.handle.net/10236/11400]

Noda, H. 野田尚史 (2005). Komyunikeeshon notameno nihongokyôikubunpô no sekkeizu ユミュ ニケーションのための日本語教育文法の設計図. In H. Noda 野田尚史 (Ed.), Komyunikeeshon notameno nihongokyôikubunpô コミュニケーションのための日本語教育文法 (pp. 1-20). Tokyo, Japan: Kuroshio Publishers くろしお出版. ISBN 4874243347

Nohara, Y. 野原ゆかり (2009). Hatsuwa no 'wakariyasusa' o handan suru yôin: Ippan Nihonjin to bogowasha nihongokyôshi no hikaku o tooshite. 発話の「分かりやすさ」を判断する 要因一一般日本人と母語話者日本語教師の比較を通して [Factors that determine explicitness of speech: A comparison of Japanese general public and native Japanese language teachers]. Ningen bunka sôsei kagaku ronsô 人間文化創成科学論叢 [Journal of the Graduate School of Humanities and Sciences], 11, 165-174.

[http://hdl.handle.net/10083/34655]

Nohara, Y. 野原ゆかり (2011). Nihongogakushûshano kôtôsetumaini taisuru bogowashano hyôka: hyôkakomentono shitsutekibunsekiniyoru jireikenkyû 日本語学習者の口頭説明 に対する母語話者の評価: 評価コ外の質的分析による事例研究[Native speakers' evaluations of Japanese learners' utterances: Case studies with qualitative analyses of evaluation Comments]. Hikakubunkakenkyû 比較文化研究[Journal of the Japan Association of Comparative Culture], 99, 69-80.

Poyatos, F. (1992) The audible-visual approach to speech as basic to nonverbal communication research. In Fernando P. (Ed.). Advances in Nonverbal Communication: Sociocultural, Clinical, Esthetic and Literary Perspectives. (pp. 41-57). Amsterdam: John Benjamins. ISBN 9027220859.

Saito, K., \& Akiyama, Y. (2017). Linguistic correlates of comprehensibility in second language Japanese speech. Journal of Second Language Pronunciation, 199-217. DOI 10.1075/jslp.3.2.02sai

Sato, S., Takami, T., Kamiyoshi, U., \& Kumagai, Y. 佐藤慎司・高見智子·神吉宇一・熊谷由理 (2015). Miraiwotsukuru kotobano kyôikuwomezashite-naiyôjûshino hihantekigengokyôiku Critical Content-Based Instruction no riron to jissen 未来を創るこ とばの教育をめざしてー内容重視の批判的言語教育 Critical Content-Based Instruction 
の理論と実践 [Language education for social future: Critical Content-Based Instruction]. Nihongokyôikugakukenkyû 日本語教育学研究 6. Tokyo, Japan: Koko shuppan ココ出版 [Coco Publishing].

Shimonaka, Y., Nakazato, K., Gondo, Y., \& Takayama, M. 下仲順子・中里克治権藤恭之・高山 緑 (1998) NihonbanNEO-PI-R no sakuseito sono inshitekidatouseino kentô 日本版 NEOPI-R の作成とその因子的妥当性の検討[Construction and factorial validity of the Japanese NEO-PI-R]. Seikakushinrigakukenkyû 性格進学研究[The Japanese Journal of Personality], 6 (2), 138-147.

Siegal, M. (1994). Second-language learning, identity, and resistance: White women studying Japanese in Japan. Culture Performances, Proceedings of the Third Berkeley Women and Language Conference, (pp. 642-650). Berkeley, CA: Berkeley Women and Language Group. ISBN 10 999773596X

Siegal, M. (1995). Individual differences and study abroad: Women learning Japanese in Japan. In Freed F., Barbara, (Ed.), Second Language Aquisition in a Study Abroad Context, (pp. 225-244), Philadelphia, PA: John Benjamins, B.V. ISBN 9781556195426

Siegal, M. (1996). The role of learner subjectivity in second language socio-linguistic competency: Western women learning Japanese. Applied Linguistics, 17, 356-382. DOI https://doi.org/10.1093/applin/17.3.356

Tsurutani, C. (2010) Foreign accent matters when timing is wrong. In Proceedings of Interspeech 2010, (pp.1854-1857). http://hdl.handle.net/10072/36647, Accessed 5 Feb 2019

Usami, Y., Mori, A., \& Yoshida, S. 宇佐美洋・森篤嗣・吉田さち (2009). Gaikokujin ga kaita nihongotegamibun ni taisuru nihonjin no hyôkataido no tayôsei; shitsutekishuhô niyoru keesusutadei. 外国人が書いた日本語手紙文に対する日本人の評価態度の多様性: 質 的手法によるケーススタディ[Diversity in Japanese native speaker attitudes when evacuating letters written by non-natives: a qualitative method case study]. Shakaigengokagaku 社 会言語科学 [The Japanese Journal of Language in Society], 12 (1), 122-134. ISSN 13443909

Watanabe, T. 渡部倫子 (2005a). Purasuhyôka, mainasuhyôka sareyasui hatsuwa no yôso towa: Nihongogakushûsha nitaisuru nihongowasha no hyôka. プラ久評価・マ什久評価され やすい発話の要素とは:日本語学習者に対する日本語母語話者の評価 Kyôikugakukenkyûjânaru 教育学研究ジャーナル[The Journal of Educational Research], 1, 7781. DOI 10.20677/csssej.1.0_77

Watanabe, T. 渡部倫子(2005b). Nihongogakushûsha no hatsuwa nitaisuru nihongobogowasha no hyôka: kyôbunsankôzôbunseki niyoru hyôkakijun no kaimei 日本 語学習者の発話に対する日本語母語話者の評価一共分散構造分析による評価基準 の解明. Nihongokyôiku 日本語教育 [Journal of Japanese Language Teaching], 125, 6775. ISSN 03894037

Yoshida, S. 吉田さち (2014). Nihongogakushûsha no gengo un'yô nitaisuru nihongobogowasha no hyôka: Bamen niyori bogowasha no hyôka wa kotonaruka 日本語 学習者の言語運用に対する日本語母語話者の評価: 場面により母語話者の評価は 異なるか [Native Japanese speakers' evaluations of Japanese-learners' linguistic performance: Do Native Japanese speakers' evaluations differ according to the 
situation?]. Komyunikêshonbunka コミュニケーション文化[Communication in Culture], 8, 27-43. ISSN 18818374

\section{Appendix A}

Facebook Project Reflection Log

About Video \#1: Self-Introduction-Converying the self in a foreign language

1. How would you describe yourself? Write the key words that capture how you see yourself.

2. Do you think you were able to show "yourself" as you intended to in a Facebook video?

Yes / No

3. If YES $\rightarrow$ What kind of things did you try, or how did you show who you are in the video? (verbal/non-verbal/others)

If NO $\rightarrow$ Why do you think you couldn't show who you were? What was difficult about it? 